\title{
Pleomorphism in the Antarctic flagellate Pyramimonas gelidicola (Prasinophyceae, Chlorophyta)
}

\author{
John van den Hoff \& John M. Ferris ${ }^{\dagger}$ \\ Australian Antarctic Division, 203 Channel Highway, Kingston 7050 Tasmania, Australia \\ †Deceased
}

\author{
Keywords \\ Antarctica; life history; pleomorphism; \\ Prasinophyceae; Pyramimonas.

\section{Correspondence} \\ John van den Hoff, Australian Antarctic \\ Division, 203 Channel Highway, Kingston \\ 7050, Tasmania, Australia. E-mail: \\ john_van@aad.gov.au
}

doi:10.1111/j.1751-8369.2009.00123.x

\begin{abstract}
Species of the genus Pyramimonas (Prasinophyceae) are a common, widespread, but minor component of the Antarctic marine phytoplankton. They are often associated with the seasonal sea-ice environment. Pyramimonas gelidicola (McFadden, Moestrup \& Wetherbee, 1982) was isolated from the water column of a saline Antarctic lake, and observations on the organism's life history as it grew in unialgal cultures were made. The alga proved to be pleomorphic: capable of producing several morphologically distinct life stages. We recorded motile single-celled quadriflagellates that formed two statistically distinct size classes, a rare uniflagellate cell-type, and aggregations of quadriflagellate cells, multilobed forms and an encystment stage. Multilobed forms and cell aggregations, never before observed in an Antarctic Pyramimonas species, are presumed to be growth medium-induced morphotypes. Multilobed forms contained an equal number of nuclei and lobes, suggesting that they are the product of asexual reproduction. Some of the morphotypes we report here may never be observed under natural field conditions, but the potential for this alga to alternate between morphotypes is clearly demonstrated.
\end{abstract}

The green algal genus Pyramimonas Schmarda, 1850 is well represented in polar waters (Daugbjerg \& Moestrup 1993). From Antarctic waters, McFadden et al. (1982) first described Pyramimonas gelidicola (Prasinophyceae) after it was isolated from sea-ice samples taken in Prydz Bay, and water samples collected at Rookery Lake and Ace Lake in the Vestfold Hills, East Antarctica. Since then, two more species, Pyramimonas tychotreta (Daugbjerg, 2000) and Pyramimonas australis (Moro et al., 2002) have been described from coastal Antarctic waters.

The life cycles of the known Antarctic Pyramimonas species currently include an encystment stage for $P$. gelidicola (van den Hoff et al. 1989; Daugbjerg et al. 2000) and a uniflagellate stage that Daugbjerg et al. (2000) considered to be a gamete of $P$. tychotreta. The formation of a resistant, cyst stage was presumed to be a response to environmental stress, but recently Daugbjerg et al. (2000) found germinating cysts and encysting cells co-occurring in field samples, leading them to suspect that no single abiotic factor regulated the formation of those stages.
The environmental stimuli required to germinate cysts remains unknown for several Pyramimonas species (Belcher 1969; van den Hoff et al. 1989), but in others a return from darkness to a low light regime and fresh media triggered excystment (Hargraves \& Gardiner 1980; Aken \& Pienaar 1981).

An additional life stage, a multilobe form (termed pleomorph cells by Aken \& Pienaar 1981) has been observed for two Pyramimonas species: Pyramimonas amylifera and Pyramimonas parkeae (Hargraves \& Gardiner 1980; Aken \& Pienaar 1981). Multilobed stages are most probably a culturally induced stage, having never been reported from the wild, and their frequency of occurrence in culture seems to be temperature dependent (Hargraves $\&$ Gardiner 1980). Individual lobes possess a complete set of flagella and have been seen breaking away from the main cellular mass, suggesting that the stage is implicated in the regeneration of the vegetative cell type (Hargraves $\&$ Gardiner 1980). Autogamy may take place within the structure (Hargraves \& Gardiner 1980), but this remains unconfirmed. 
Here, we report on different morphotypes produced by $P$. gelidicola in culture, discuss the morphological and functional similarities with other Pyramimonas species and propose an in vitro life cycle for the species.

\section{Materials and methods}

The sample collection, cell culture and microscope observation methods for the investigation of $P$. gelidicola cells from Ace Lake, Antarctica, have been detailed previously in van den Hoff et al. (1989). The culture material upon which the previous study and this study were based no longer exists, but the Ace Lake strain of P. gelidicola is held at the CSIRO Marine and Atmospheric Research Microalgae Supply Service.

Cell dimensions were measured with an eyepiece graticule, and cell sizes $(\mu \mathrm{m})$ are expressed as means \pm standard deviations. Cellular nucleic acids were stained with the fluorochrome 4',6-diamidino-2phenylindole (DAPI) at final concentrations of $0.2 \mu \mathrm{g} \mathrm{mL}^{-1}$ for glutaraldehyde-fixed samples, and at $1-2 \mu \mathrm{gLL}^{-1}$ for living material (Coleman 1985). DAPI-stained cells were viewed using a PM2 spectrophotometer (Carl Zeiss, Oberkochen, Germany) with UV epifluorescence excitation (G365 exciter filter, FT395 dichroic beam splitter and a LP420 barrier filter).

\section{Results}

Pyramimonas gelidicola produced a number of distinct morphotypes when grown under identical environmental conditions in either F/2 or GP growth media (Fig. 1).

\section{Quadriflagellate cells}

We observed two different-sized motile quadriflagellate cell types: a small cell type and a larger, rounder cell type (Fig. la). The small cells measured $12.0 \pm 1.2 \mu \mathrm{m}$ in length, and $9.9 \pm 0.8 \mu \mathrm{m}$ in diameter $(n=13)$; each cell had four flagella, and appeared to contain a central pyrenoid and lipid inclusions surrounding the flagella depression. The larger cells were rounder, measuring $15.7 \pm 2.5 \mu \mathrm{m}$ in length and $14.2 \pm 2.5 \mu \mathrm{m}$ in diameter $(n=17)$. Student's $t$-test comparisons of the means showed that these cell types formed two distinctly different size classes (cell length, $t$-value $=-4.93$, d.f. $=28, P<0.001$; cell width, $t$-value $=-5.80$, d.f. $=28$, $P<0.001$ ). Dividing cells (Fig. 1b) had two sets of four flagella and two pyrenoids. Cell division began at the flagella depression, and continued until the cells remained joined only at the posterior end (Fig. lc).

\section{Uniflagellate cells (Fig. 1d)}

Cells possessing only a single flagellum measured $12.6 \pm 0.7 \mu \mathrm{m}$ in length, and $10.2 \pm 0.3 \mu \mathrm{m}$ in diameter $(n=5)$. These cells contained an enlarged starch reserve and numerous lipid droplets dispersed throughout the apical half of the cells. A single flagella with a terminal swelling (perhaps induced by the fixation procedure) emerged from an apical depression. This cell type was rare, and therefore no scanning electron microscope (SEM) or transmission electron microscope observations could be made to determine whether scales were present on the periplast and flagella.

\section{Cell aggregations (Fig. 1e)}

Aggregations of usually four, but sometimes up to eight, very closely associated single-celled quadriflagellates were observed. Unlike the multilobed stages (described below), each cell within the aggregation retained its own integrity. Cell aggregations were very active, beating their flagella rapidly.

\section{Multilobed forms (Fig. 1f, g)}

Multilobed forms had between three and eight lobes. A common periplast surrounded the mass, and each lobe had four active flagella. Eight-lobed forms consisted of two, four-lobed forms joined by an isthmus (Fig. 1g). This morphotype had a covering of periplast and flagella scales that are typical of the motile quadriflagellate (Fig. If), thereby confirming they were a product of the quadriflagellate cell. The eight-lobed example shown in Fig. Ig lacks scales, perhaps as a result of individual differences in fixation. Single motile cells were observed (but not photographed) in live culture during the process of budding from multilobed masses.

Nuclear DNA staining (DAPI) revealed that a single nucleus was present within each lobe, perhaps indicating that nuclear division had taken place within the mass, or that a number of quadriflagellate cells had fused. Unfortunately, only drawings were made of this aspect of the study, and so no photographs are presented here. The nuclei in deeply invaginated forms were most often located nearer the flagella pits, but were more central in rounder forms, suggesting that these forms were at a different stage of cell division compared with the deeply invaginated forms.

On one occasion, a four-lobed form was seen (and drawn) with a thick cyst-like wall within a thinnerwalled membrane. DAPI staining showed that the cell contained a single distinct nucleus and a separate dispersed region of DNA. 

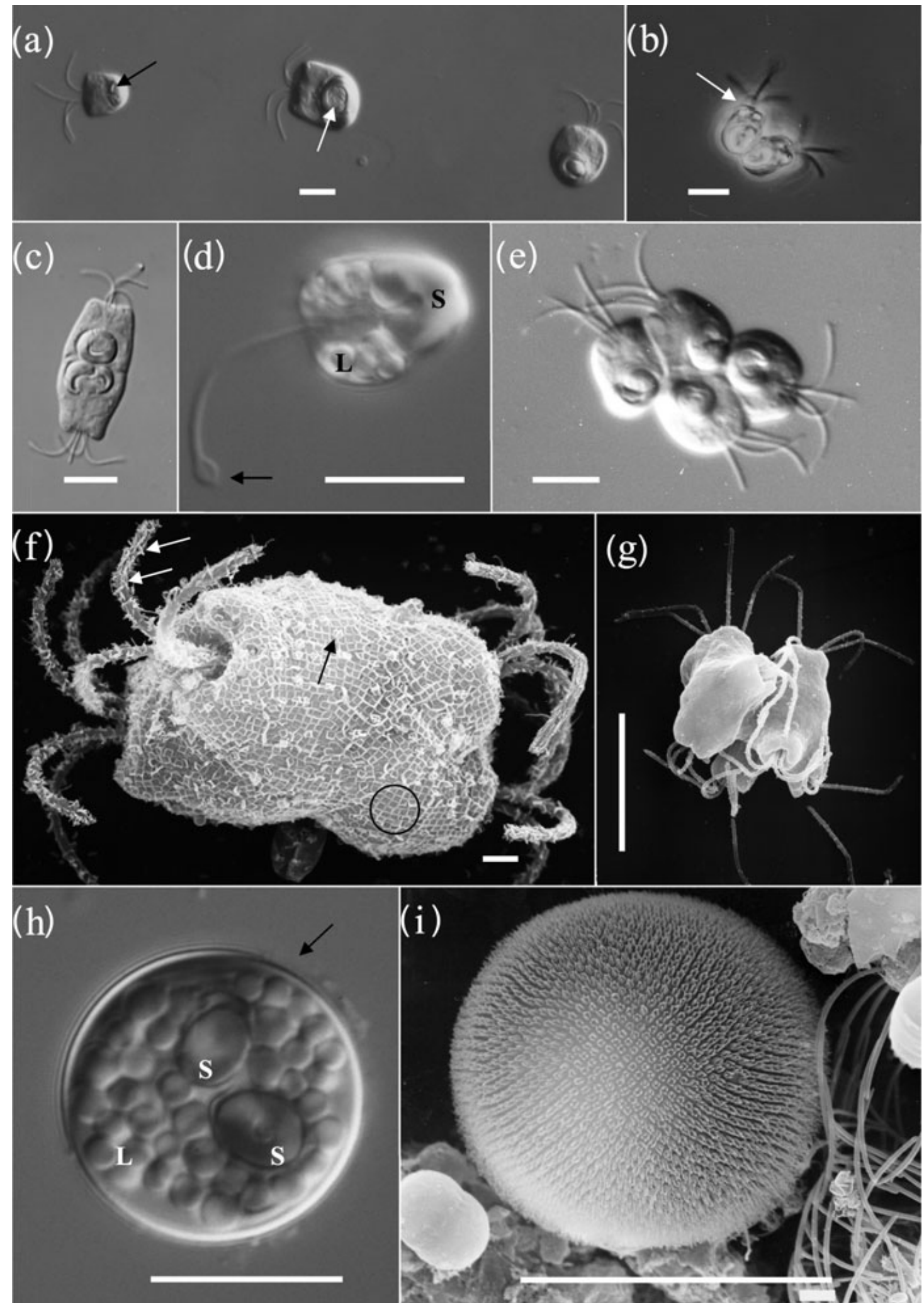
Fig. 1 Light micrographs (LMs) and scanning electron micrographs (SEMS) of the morphologically distinct life stages observed in growth cultures of the Antarctic Prasinophyte Pyramimonas gelidicola. Scale bars: $10 \mu \mathrm{m}$; except in (f), 1 mm. (a) Nomarski LM of glutaraldehyde-fixed small (T-cell) and large (L-cell) quadriflagellate cells. Note the enlarged starch reserve in the central L-cell (white arrow) compared with the smaller T-cell (black arrow). (b) Phase contrast LM of a living dividing quadriflagellate cell. Cell division has begun at the anterior (flagella) of the cell. According to McFadden et al. (1982), the refractive bodies (white arrow) lying within the flagella collar are lipids. (c) Nomarski LM of a glutaraldehyde-fixed dividing cell still joined at the posterior end. A further incomplete division at this stage could produce the pleomorph cell type shown in (f). (d) Nomarski LM of a uniflagellate cell type. Note the starch (S) and lipid (L) droplets, similar to those seen in the encystment stage (h). The swollen flagella tip (arrow) is likely to be an artefact of sample preparation. (e) Nomarski LM of an "aggregation" of four quadriflagellate cells. (f) SEM of a four-lobed stage possessing a near full complement of four flagella in each flagella pit. The periplast has a covering of body (black circle) and crown scales (black arrows), and the flagella are covered in Limulus scales (white arrows). These scale types are typical of motile quadriflagellate $P$. gelidicola cells (McFadden et al. 1982). (g) SEM of an eight-lobed morphotype. The mass shown here has no body or flagella scales, which were perhaps lost during the fixation process for this individual. The example has multiple flagella per lobe, and an isthmus separating the two four-lobed cell masses. (h) Nomarski LM of a cyst cell, showing the thick cell wall (arrow), two starch grains (S) and numerous lipid (L) droplets. (i) SEM of a cyst showing the cyst scale type that differs from scales found on the quadriflagellate. This cell was observed in freshly collected and preserved Ace Lake water.

Table 1 Comparisons of morphotypes reported (+) or not yet reported (-) in the literature for selected Pyramimonas (Prasinophyceae) species. Antarctic species are set in bold; RS, Ross Sea; WS, Weddell Sea.

\begin{tabular}{llllll}
\hline $\begin{array}{l}\text { Pyramimonas } \\
\text { species }\end{array}$ & $\begin{array}{l}\text { Small and large } \\
\text { cell types }\end{array}$ & $\begin{array}{l}\text { Multilobed } \\
\text { stage }\end{array}$ & $\begin{array}{l}\text { Uniflagellate } \\
\text { cell type }\end{array}$ & $\begin{array}{l}\text { Cyst } \\
\text { stage }\end{array}$ & Reference \\
\hline P. gelidicola & + & + & + & + & This study \\
P. tychotreta WS & - & - & - & - & Daugbjerg 2000 \\
P. tychotreta RS & - & - & + & + & Daugbjerg et al. 2000 \\
P. australis & - & - & - & + & Moro et al. 2002 \\
P. amylifera & - & + & - & + & Hargraves \& Gardiner 1980 \\
P. parkeae & + & + & - & + & Aken \& Pienaar 1981 \\
P. pseudoparkeae & + & - & - & Pienaar \& Aken 1985 \\
\hline
\end{tabular}

\section{Cysts (Fig. 1h, i)}

Light micrographs (LMs) revealed thick-walled cysts contained varying numbers of starch grains and numerous lipid droplets (Fig. 1h). Cysts were spherical $(\varnothing=17.2 \pm 3.4 \mu \mathrm{m}, n=23)$, and SEM showed a covering of spine-scales (Fig. li), consistent with a previous study (van den Hoff et al. 1989).

\section{Discussion}

As a first point of discussion it is important to affirm that the morphotypes we report here are life stages of $P$. gelidicola and no other species. The water samples from which the culture material originated were collected from Ace Lake, a well-studied Antarctic saline lake (e.g., Burch 1988; Laybourn-Parry et al. 2002; Bell \& Laybourn-Parry 2003) known to contain a cyst-producing quadriflagellate species described as P. gelidicola (McFadden et al. 1982; van den Hoff et al. 1989). The unialgal cultures used in this study have been confirmed to contain P. gelidicola (van den Hoff et al. 1989). The presence of box, crown, limulus and pentagonal scales on the periplast and flagella of a multilobed stage (Fig. If) lends support to this identity of the species, and also indicates that the multilobed form is the product of $P$. gelidicola itself.
Pyramimonas gelidicola has the capability of producing several morphologically distinct life stages (i.e., pleomorphism), albeit under enrichment culture conditions. The cultures contained morphotypes that have never before been observed in Antarctic Pyramimonas species, but which have previously been reported for other Pyramimonas species (Table 1). Changes in growth culture conditions over time (e.g., nutrient depletion) possibly stimulated the occurrence of these life stages, so perhaps they may never be observed under natural field conditions. However, the encystment stage seen in culture has been observed from field collections (Fig. li; van den Hoff et al. 1989).

Three species isolated from Antarctic waters (P. gelidicola, P. tychotreta and P. australis) are known to produce an encystment stage (Table 1). The cysts of $P$. gelidicola and $P$. tychotreta are barely distinguishable from each other: both are round, have a thick tri-layered cell wall and have a covering of spiny cyst scales that differ from the quadriflagellate cell type (van den Hoff et al. 1989; Daugbjerg 2000). The Pyramimonas cyst formation began with the motile single-celled quadriflagellate (van den Hoff et al. 1989; Daugbjerg 2000; Moro et al. 2002), but cysts could also be the product of the multilobed stage observed in culture, because we saw on one occasion a multilobed form containing a thickened internal cyst-like 
wall structure, a single nucleus and a diffuse mass of DNA. Perhaps the region of diffuse DNA in this cell resulted from the dissolution of other nuclei during cyst formation. Alternatively, the diffuse nuclear material seen resulted from cell damage during fixation. Given that we lack observations on germinating cysts, we propose that in $P$. gelidicola, the process is likely to be similar to that in P. tychotreta (Daugbjerg et al. 2000), in which the contents of cysts ultimately divided into four quadriflagellate cells that were released through a rupture in the cyst wall. The Antarctic environment is extreme and highly changeable, and an encystment stage is one mechanism by which the Pyramimonas species can tolerate such changes and survive the extremes of the Antarctic environment.

A variety of morphotypes observed here for $P$. gelidicola have been reported previously for $P$. amylifera (Hargraves \& Gardiner 1980), P. parkeae (Aken \& Pienaar 1981), Pyramimonas pseudoparkeae (Pienaar \& Aken 1985), P. tychotreta (Daugbjerg et al. 2000) and P. australis (Moro et al. 2002) (Table 1). The P. gelidicola cultures contained two statistically different-sized single cell types (Fig. la). Two different-sized vegetative cell types have been observed in P. parkeae (Aken \& Pienaar 1981) and $P$. pseudoparkeae (Pienaar \& Aken 1985). The motile multilobed stages (Fig. If, g), with up to eight lobes, of $P$. gelidicola were similar in appearance to those of $P$. amylifera (Hargraves \& Gardiner 1980: fig. 14) and, to a lesser extent, to stage 7 of $P$. parkeae (Aken $\delta$ Pienaar 1981: fig. 1). With the use of a DNA stain (DAPI), we report here that these are multinucleate stages, in most cases with an equal number of nuclei and lobes. As with Hargraves \& Gardiner's observations in 1980, we cannot comment on whether autogamy takes place at any time within the cell mass.

Multilobed stages of Pyramimonas have yet to be observed in nature, or in the two other Antarctic Pyramimonas species (Table 1). Hargraves \& Gardiner (1980) described how differing environmental conditions produced varying numbers of $P$. amylifera multilobed stages in their cultures: the numbers were inversely correlated with temperature. For the present study, the temperature and light intensity were held constant, and thus the effects of manipulating these parameters were not investigated. However, the presence of various different morphological stages in the cultures suggests factors other than light and temperature are involved in their production. Experimental manipulations would provide valuable information on how the life stages for P. gelidicola may change under growth conditions that model possible climatic change scenarios.

From our limited observational record, binary fission in P. gelidicola (Fig. 1b, c) was most similar to that described for P. australis (Moro et al. 2002), P. parkeae (Aken $\delta$ Pienaar 1981) and, to a lesser degree, with $P$. amylifera (Hargraves \& Gardiner 1980) and Pyramimonas quadrifolia (Daugbjerg \& Moestrup 1993). Like P. parkeae, cells of $P$. gelidicola can remain joined at the posterior (Fig. 1c) for an undetermined period. A further incomplete division of such a cell at this time could result in the formation of a multilobed stage (Fig. If). As with P. amylifera, such stages of $P$. gelidicola could be the product of incomplete cell division caused by a lack, or oversupply, of a culture medium component(s) critical to cytokinesis (Hargraves \& Gardiner 1980). Deeply invaginated forms are possibly at a more advanced period in their cell division processes than the more spherical forms.

The budding of single lobes from a multilobed stage may be one mechanism by which the quadriflagellate is regenerated; this process has been observed for $P$. amylifera (Hargraves \& Gardiner 1980) and P. parkeae (Aken \& Pienaar 1981). The budding of single cells most likely occurs when the cell mass is at a deeply invaginated stage (i.e., where the cells are barely joined at the posterior). Multilobed stages with an odd number of lobes were observed in our cultures, suggesting that a single cell had broken free through vegetative budding from the main cell mass.

Aggregations of, usually four, very vigorously swimming quadriflagellate cells were seen in cultures. These masses were distinguishable from the multilobed forms because, although closely associated with each other, each cell remained separate from other cells within the mass (Fig. 1e). To our knowledge, no Pyramimonas species are previously known to produce such a life form. Whether these cells were aggregating, disaggregating or the product of excystment remains unresolved.

We also observed, with LMs only, a uniflagellate form of the vegetative cell type (Fig. 1d). Daugbjerg et al. (2000) saw such a form in P. tychotreta samples freshly collected from the wild, and, based on ultrastructural observations and scale morphology, they linked the uniflagellate to $P$. tychotreta, rather than reporting it as a new species. Uniflagellate cells differed morphologically between the two species: in P. gelidicola, the cell shape was more like the quadriflagellate, whereas in $P$. tychotreta it was a rather more elongate cigar shape, compared with the quadriflagellate. Daugbjerg et al. (2000) suggested that these cell types may represent a gamete, implying the occurrence of sexual reproduction in the life cycle of P. tychotreta. We cannot comment on the occurrence or otherwise of sexual reproduction in P. gelidicola, except to say that the presence of an unusual uniflagellate form in both $P$. tychotreta and $P$. gelidicola suggests that an alternative to asexual reproduction of the quadriflagellate is possible. 
Fig. 2 Proposed life cycle for Pyramimonas gelidicola in culture. The three alternative routes by which the quadriflagellate cell can reproduce are shown as Loops 1, 2 and 3 . From our current understanding, the uniflagellate cell type and cell aggregations cannot be placed in the life cycle. Scale bar: $20 \mu \mathrm{m}$. The solid lines are the reported process for $P$. gelidicola. The dashed line is the speculative process for $P$. gelidicola, but is known for other Pyramimonas species.

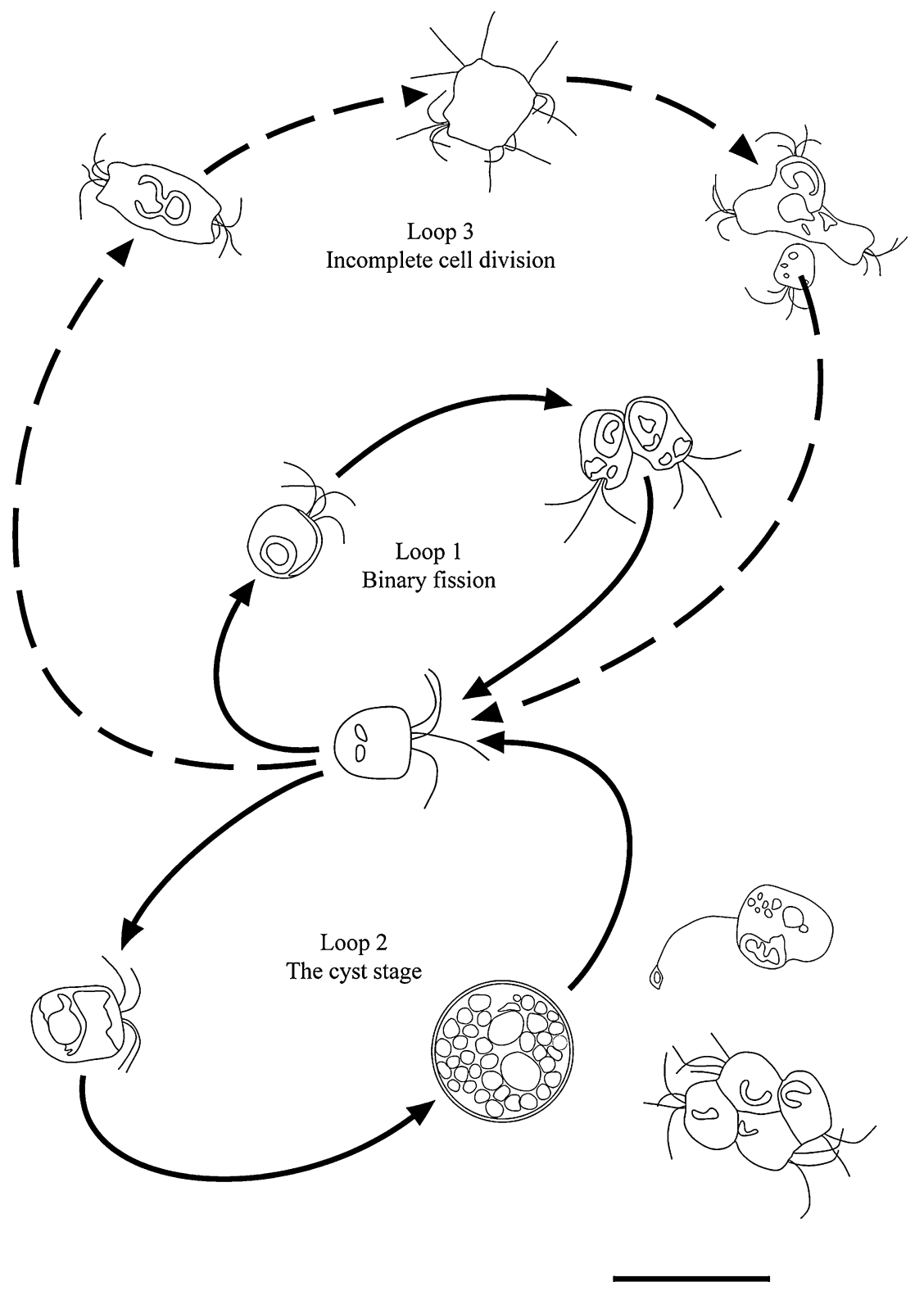

Overall, we lack real-time video footage of cells as they progressed through the various morphological stages, and thus the life cycle for P. gelidicola that we present in Fig. 2 is purely conceptual. The model conceived draws on limited observations for P. gelidicola, combined with those from other Pyramimonas species (Hargraves \& Gardiner 1980; Aken \& Pienaar 1981; Daugbjerg et al. 2000). Until proven otherwise, note that this model is only representative of the species growing under culture conditions.

The model suggests three alternative cellular processes by which vegetative cells could reproduce. Firstly, duplicating the population through binary fission of the singlecelled quadriflagellate (Loop 1 in Fig. 2). Secondly, via the processes of encystment of the single cell and the subsequent excystment of a number of single cells (Loop 2 in Fig. 2). Thirdly, cell multiplication could proceed via budding in the multilobed stage (Loop 3 in Fig. 2). Our observations do not allow us to make any comment on the possibility that DNA recombination takes place in multilobed stages, and, like Daugbjerg et al. (2000), we found it difficult to place the uniflagellate form of $P$. gelidicola into a proposed life history, and so we make no attempt to do so. The significance of the cell aggregations is also unresolved.

Although it is unfortunate the original culture material that we isolated from Ace Lake is no longer available, and 
that the work has not been followed up more recently, we feel it would be fruitful for others to investigate the causes of these aberrant cells in culture.

\section{Acknowledgements}

Andrew Davidson, Fiona Scott and Øjvind Moestrup made constructive comments on early drafts of the paper. Deborah Riewesthal produced the life-cycle figure. As a result of the journal referees' comments, this is a muchimproved paper.

\section{References}

Aken M.E. \& Pienaar R.N. 1981. Observations on the reproduction of Pyramimonas parkeae Norris et Pearson (Prasinophyceae). South African Journal of Science 77, 330-331.

Belcher J.H. 1969. Further investigations on the type species of Pyramimonas (P. tetrarhynchus Schmarda) (Prasinophyceae): an examination by light microscopy, together with notes on its taxonomy. Botanical Journal of the Linnaean Society 62, 241-253.

Bell E.M. \& Laybourn-Parry J. 2003. Mixotrophy in the Antarctic phytoflagellate, Pyramimonas gelidicola (Chlorophyta: Prasinophyceae). Journal of Phycology 39, 644-649.

Burch M.D. 1988. Annual cycle of phytoplankton in Ace Lake, an ice covered, saline meromictic lake. Hydrobiologia 165, 59-75.

Coleman A.W. 1985. Cyanophyte and cyanelle DNA: a search for organelles in plastids. Journal of Phycology 21, 371-379.
Daugbjerg N. 2000. Pyramimonas tychotreta, sp. nov. (Prasinophyceae), a new marine species from Antarctica: light and electron microscopy of the motile stage and notes on growth rates. Journal of Phycology 36, 160-171.

Daugbjerg N., Marchant H.J. \& Thomsen H.A. 2000. Life history stages of Pyramimonas tychotreta, sp. nov. (Prasinophyceae, Chlorophyta), a marine flagellate from the Ross Sea, Antarctica. Phycological Research 48, 199-209.

Daugbjerg N. \& Moestrup Ø. 1993. Four new species of Pyramimonas (Prasinophyceae) from Arctic Canada including a light and electron microscope description of Pyramimonas quadrifolia sp. nov. European Journal of Phycology 28, 3-16.

Hargraves P.E. \& Gardiner W.E. 1980. The life history of Pyramimonas amylifera Conrad (Prasinophyceae). Journal of Plankton Research 2, 99-108.

Laybourn-Parry J., Quayle W. \& Henshaw T. 2002. The biology and evolution of Antarctic saline lakes in relation to salinity and trophy. Polar Biology 25, 542-552.

McFadden G.I., Moestrup Ø. \& Wetherbee R. 1982. Pyramimonas gelidicola sp. nov. (Prasinophyceae), a new species isolated from Antarctic sea ice. Phycologia 21, 103-111.

Moro I., La Rocca N., Dalla Valle L., Moschin E., Negrisolo E. \& Andreoli C. 2002. Pyramimonas australis sp. nov. (Prasinophyceae, Chlorophyta) from Antarctica: fine structure and molecular phylogeny. European Journal of Phycology 37, 103-114.

Pienaar R.N. \& Aken M.E. 1985. The ultrastructure of Pyramimonas pseudoparkeae sp. nov. (Prasinophyceae) from South Africa. Journal of Phycology 21, 428-447.

van den Hoff J., Burton H.R. \& Vesk M. 1989. An encystment stage, bearing a new scale type, of the prasinophyte Pyramimonas gelidicola and its paleolimnological and taxonomic significance. Journal of Phycology 25, 446-454. 